\title{
Ultrasonic synthesis and crystal structure analysis of two trimethylsilyloxy-substituted bicyclo[2.2.2] octene derivatives
}

\author{
H T SRINIVASA $^{\mathrm{a}}$, H NAGARAJAIAH ${ }^{\mathrm{a}}$, B S PALAKSHAMURTHY ${ }^{\mathrm{b}}$, \\ $S$ HARIPRASAD ${ }^{\mathrm{a}}$ and NOOR SHAHINA BEGUM ${ }^{\mathrm{a}, *}$ \\ ${ }^{a}$ Department of Studies in Chemistry, Central College Campus, Bangalore University, \\ Dr. B R Ambedkar Street, Bangalore 560 001, India \\ ${ }^{b}$ Department of Post Graduate Studies and Research in Physics, Tumkur University, Tumkur 572 103, India \\ e-mail: noorsb@rediffmail.com; noorsb05@gmail.com
}

MS received 27 August 2012; revised 25 May 2013; accepted 4 July 2013

\begin{abstract}
The compounds: 11-trimethylsilyloxy-1,2,3,4,4a,9a-hexahydro-1,4-etheno-anthraquinone and 4-benzyl-8-trimethylsilyloxy-4-aza-tricyclo[5.2.2.0]undec-8-ene-3,5-dione were synthesized by the DielsAlder $\left[4 \pi_{s}+2 \pi_{s}\right]$ cycloaddition reaction of 2-(trimethylsilyloxy)-1,3-cyclohexadiene with naphthaquinone and $N$-benzylmaleimide under ultrasonic conditions. The crystal structure analysis was done using single crystal X-ray diffraction method. In both the compounds, the trimethylsilyloxy- and naphthaquinone/ $\mathrm{N}$-benzylmaleimide moieties are endo- to the bicyclic ring.
\end{abstract}

Keywords. Ultrasonication; trimethylsilyloxy-derivatives; bicyclo[2.2.2]octene; Diels-Alder reaction; crystal structure; $\mathrm{C}-\mathrm{H}$. . . O and $\pi \ldots \pi$ interactions.

\section{Introduction}

The atomic radius of silicon is larger than carbon, whereas the electronegativity of silicon is lower in comparison to carbon. ${ }^{1}$ However, when elemental silicon is converted into organosilyl- based reagents, the silyl- groups behave as weak electron donating groups, becoming prone to attack by nucleophiles. ${ }^{2}$ This renders the organosilyl- moiety to behave as anionic synthons. The synthons have wide applications in synthetic organic chemistry.

Cyclohexa-1,3-dienes and silyl- substituted 1,3cyclohexadienes have been used for construction of the bicyclo[2.2.2] octene derivatives employing the DielsAlder $\left[4 \pi_{s}+{ }_{2} \pi_{s}\right]$ reaction. ${ }^{3}$ Recent work has shown that the endo-product is invariably predominant in the reaction of dienes with dienophiles. ${ }^{4}$ The formation of the endo- isomer plays an important role in the design of drugs, ${ }^{5}$ natural products ${ }^{6}$ and other organosilicon based reagents. ${ }^{7}$ Recently, the quantitative relationship between structural studies and reactivity properties of silyl- derivatives were studied. ${ }^{8}$ The structural studies indicated a self-assembly facilitated via the rare co-existence of dimeric and catemeric patterns of bicyclo[2.2.2] octadiene, bicyclo[2.2.2]octane

*For correspondence and bis(trimethylsilyl)-5-norbornene skeletons, respectively. ${ }^{9,10}$ All these parameters were attributed to the influence of the trimethylsilyl- group.

These findings prompted us to synthesize compounds 11-trimethylsilyloxy-1,2,3,4,4a,9a-hexahydro-1,4-ethenoanthraquinone (3a) and 4-benzyl-8-trimethylsilyloxy4-aza-tricyclo[5.2.2.0 $\left.0^{2,6}\right]$ undec-8-ene-3,5-dione (3b). The single crystal X-ray diffraction studies revealed that the product with endo- stereospecific geometry is preferred over the exo- product in the Diels-Alder cycloaddition reactions.

\section{Experimental}

\subsection{Materials and characterization}

All the chemicals were reagent grade and used as such without purification. Ultrasonic reactions were performed using OSCAR ultrasonic cleaner-109 (9.5 litres, $34 \mathrm{KHz}$ power and 250 watts ultrasonic power). The reactions were monitored using TLC and the products purified by column chromatography on silica gel (60-120) mesh using 5\% ethyl acetate in hexane as an eluent. The compounds were crystallized with ethyl acetate to get good crystals for crystallographic studies. IR spectra were recorded on Shimadzu FTIR-8400 spectrophotometer. The structures were confirmed 
using ${ }^{1} \mathrm{H}-\mathrm{NMR},{ }^{13} \mathrm{C}-\mathrm{NMR}$ (Bruker 400 spectrometer). Elemental analyses were obtained using CarloErba1106 analyser.

2.2 Experimental procedure for the preparation of 11-trimethylsilyloxy-1,2,3,4,4a,9a-hexahydro-1,4etheno-anthraquinone (3a) and 4-ben zyl-8trimethylsilyloxy-4-aza-tricyclo[5.2.2.0 $\left.0^{2,6}\right]$ undec-8-ene3,5-dione (3b)

Cyclohexenone (1) was treated with chlorotrimethylsilane and triethylamine in dimethylformamide as a solvent to obtain compound 2-(trimethylsilyloxy)1,3-cyclohexadiene (2) under classical thermal conditions. ${ }^{11}$ A mixture of naphthaquinone $(1.58 \mathrm{~g}$, $10 \mathrm{mmol})$; or $N$-benzylmaleimide $(1.87 \mathrm{~g}, 10 \mathrm{mmol})$ and 2-(trimethylsilyloxy)-1,3-cyclohexadiene (2) $(3.36 \mathrm{~g}, 20 \mathrm{mmol})$ in $10 \mathrm{~mL}$ toluene were irradiated in a water bath under ultrasonication for $2 \mathrm{~h}$ at room temperature (scheme 1). ${ }^{12}$ After completion of the reaction the solvent was removed under reduced pressure, extracted with ethyl acetate $(10 \mathrm{ml})$, washed with water and dried over anhydrous sodium sulphate. Single crystals of 11trimethylsilyloxy-1,2,3,4,4a,9a-hexahydro-1,4-ethenoanthraquinone (3a) and 4-benzyl-8-trimethylsilyloxy4-aza-tricyclo[5.2.2.0 $0^{2,6}$ undec-8-ene-3,5-dione were obtained individually by re-crystallization using ethyl acetate at room temperature.

\subsection{Physical measurements}

2.3a 11-Trimethylsilyloxy-1,2,3,4,4a,9a-hexahydro1,4-etheno-anthraquinone (3a): Yield: 92\%. M. p.: 112-113 ${ }^{\circ} \mathrm{C}$. IR: 2922, 2852 (alkyl $\left.\mathrm{CH}_{2}\right), 1680(\mathrm{C}=$ $\mathrm{O}), 1631(\mathrm{Ar}-\mathrm{CH}=\mathrm{CH}-), 1234\left(-\mathrm{OSiMe}_{3}\right) \mathrm{cm}^{-1} ;{ }^{1} \mathrm{H}-$ NMR: $\delta 8.14(\mathrm{~m}, 2 \mathrm{H}, \mathrm{Ar}-\mathrm{H}), 7.80(\mathrm{~m}, 2 \mathrm{H}, \mathrm{Ar}-\mathrm{H}), 4.95$ $(\mathrm{d}, 1 \mathrm{H}, J=2.5, \mathrm{C}=\mathrm{CH}), 3.43-3.15(\mathrm{~m}, 4 \mathrm{H}, 4 \times \mathrm{CH})$,
2.93-1.51 (m, 4H, $\left.2 \times \mathrm{CH}_{2}\right), 0.12\left(\mathrm{~s}, 9 \mathrm{H},-\mathrm{SiMe}_{3}\right)$ ppm; ${ }^{13} \mathrm{C}-\mathrm{NMR}: \delta 198.6(\mathrm{C}=\mathrm{O}), 197.6(\mathrm{C}=\mathrm{O})$, $155.9(\mathrm{C}=\mathrm{C}-\mathrm{O}-\mathrm{Si}), 136.4(-\mathrm{C}=\mathrm{C}-, \mathrm{Ar}), 132.3(\mathrm{CH}=$ $\mathrm{CH}, \mathrm{Ar}), 127.1(\mathrm{CH}=\mathrm{CH}, \mathrm{Ar}), 102.5(\mathrm{C}=\mathrm{C}-\mathrm{O})$, $51.6(\mathrm{CH}), 37.3\left(\mathrm{CH}_{2}\right), 26.5(\mathrm{CH}), 0.0\left(-\mathrm{SiMe}_{3}\right) \mathrm{ppm}$; GC-MS: $326.3[\mathrm{M}+1], 318,292,276,271,254$ [base peak], 73; Anal. Calcd for $\mathrm{C}_{19} \mathrm{H}_{22} \mathrm{O}_{3}$ Si: C, 69.90\%; $\mathrm{H}$, 6.79\%. Found: C, 69.81\%; H 6.74\%.

$2.3 \mathrm{~b}$ 4-Benzyl-8-trimethylsilyloxy-4-aza-tricyclo[5.2.2.0 $0^{2,6}$ undec-8-ene-3,5-dione (3b): Yield: $70 \%$. M. p.: $114-115^{\circ} \mathrm{C}$. IR: 2955, $2856\left(\mathrm{CH}_{2}\right), 1770$ $(\mathrm{C}=\mathrm{O}), 1633(\mathrm{Ar}-\mathrm{CH}=\mathrm{CH}-), 1251\left(-\mathrm{SiMe}_{3}\right) \mathrm{cm}^{-1}$; ${ }^{1} \mathrm{H}-\mathrm{NMR}: \delta 7.32(\mathrm{~m}, 5 \mathrm{H}, \mathrm{Ar}-\mathrm{H}), 4.86(\mathrm{~m}, 1 \mathrm{H},-\mathrm{C}=$ $\mathrm{CH}), 4.84$ (s, 2H, Ar- $\left.\mathrm{CH}_{2}-\mathrm{N}\right), 3.13-2.74(\mathrm{~m}, 4 \mathrm{H}, 4 \times$ $\mathrm{CH}), 1.58\left(\mathrm{~m}, 4 \mathrm{H}, 4 \times \mathrm{CH}_{2}\right), 0.12\left(\mathrm{~s}, 9 \mathrm{H},-\mathrm{SiMe}_{3}\right)$ ppm; ${ }^{13} \mathrm{C}-\mathrm{NMR}: \delta 178.6(\mathrm{C}=\mathrm{O}), 177.8(\mathrm{C}=\mathrm{O})$, $154.3(\mathrm{C}=\mathrm{C}-\mathrm{O}-\mathrm{Si}), 135.9(\mathrm{C}=\mathrm{C}, \mathrm{Ar}), 132.3(\mathrm{CH}=$ $\mathrm{CH}, \mathrm{Ar}), 127.6(\mathrm{CH}=\mathrm{CH}, \mathrm{Ar}), 101.3(\mathrm{C}=\mathrm{C}-\mathrm{O})$, $45.1\left(\mathrm{Ar}-\mathrm{CH}_{2}-\mathrm{N}\right), 44.5(\mathrm{CH}), 32.2\left(\mathrm{CH}_{2}\right), 25.2(\mathrm{CH})$, $0.02\left(-\mathrm{SiMe}_{3}\right)$ ppm; GC-MS: $355[\mathrm{M}+1], 189,168$, 151, 91[base peak], 73; Anal. Calcd for $\mathrm{C}_{20} \mathrm{H}_{25} \mathrm{NO}_{3} \mathrm{Si}$ : C, 67.57\%; H, 7.09\%; N 3.94\%. Found: C, 67.74\%; H $6.80 \%$; N, 3.57\%.

\section{$2.4 \quad$ X-Ray diffraction analysis}

Good quality single crystals were obtained upon recrystallization of compounds $\mathbf{3 a}$ and $\mathbf{3} \mathbf{b}$ by slow evaporation of their solutions in ethyl acetate solvent. The X-ray diffraction data, for the compounds 3a and 3b were collected on a Bruker Smart CCD Area Detector System using MoK $\alpha(0.71073 \AA)$ radiation. The data were reduced using SAINT-Plus. ${ }^{13}$ The structures were solved by direct method using SHELXS $97^{14}$ and refined by difference Fourier syntheses using SHELXL97. ${ }^{14}$ The positions and anisotropic

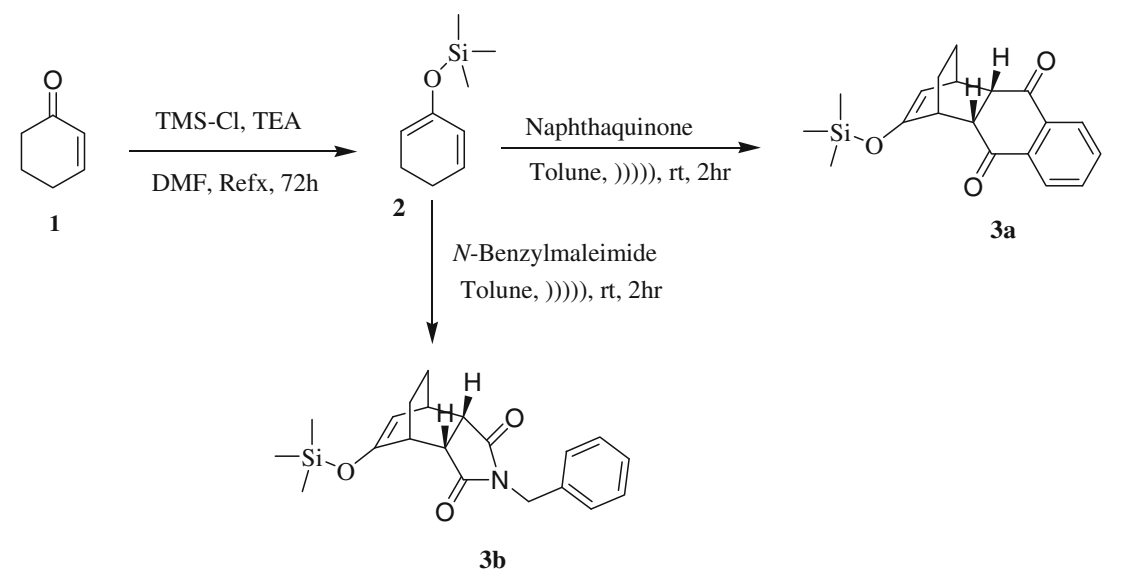

Scheme 1. Ultrasonic synthesis of compounds $\mathbf{3 a}$ and $\mathbf{3 b}$. 
displacement parameters of all non-hydrogen atoms were included in the full-matrix least-square refinement using SHELXL97 ${ }^{14}$ and the procedures were carried until convergence was reached. Then the hydrogen atoms were fixed geometrically and were refined isotropically. Molecular diagrams were generated using ORTEP. ${ }^{15}$ The mean plane calculations were done using the program PARST. ${ }^{16}$

2.4a Compound (3a): Intensity data were collected at $296 \mathrm{~K}$ in the $\omega-\Phi$ scan mode. A total of 38323 reflections were collected, resulting in 7653 [R(int) = 0.0561] independent reflections, of which the number of reflections satisfying $\mathrm{I}>2 \sigma(\mathrm{I})$ criteria were 4598 . The $\mathrm{R}$ factor on convergence $\mathrm{R}=0.0676$.

2.4b Compound ( $3 \boldsymbol{b})$ : Intensity data were collected at $296 \mathrm{~K}$ in the $\omega-\Phi$ scan mode. A total of 22289 reflections were collected, resulting in 4189 [R(int) $=$ 0.0428 ] independent reflections, of which the number of reflections satisfying $\mathrm{I}>2 \sigma(\mathrm{I})$ criteria were 3155 . The $\mathrm{R}$ factor onconvergence $\mathrm{R}=0.0451$.

\section{Results and discussion}

\subsection{Chemistry}

The infrared spectrum of compounds $\mathbf{3 a}$ and $\mathbf{3 b}$ shows a sharp band at $1251 \mathrm{~cm}^{-1}$ characteristic to the presence of trimethylsilyl- group. The IR spectrum also showed a strong band at $1770 \mathrm{~cm}^{-1}$ confirming the presence of $\mathrm{C}=\mathrm{O}$ group. In the ${ }^{1} \mathrm{H}-\mathrm{NMR}$ spectra of compound $\mathbf{3 a}$ a doublet at $\delta 4.95 \mathrm{ppm}$ indicated the vinylic proton and multiplet signal at $\delta 8.14-7.80 \mathrm{ppm}$ confirmed the aromatic protons. In compound $\mathbf{3 b}$ benzylic protons resonate at $\delta 4.84 \mathrm{ppm}$ in addition to vinylic and aromatic

Table 1. Crystal data and structure refinement of compounds $\mathbf{3 a}$ and $\mathbf{3 b}$.

\begin{tabular}{|c|c|c|}
\hline Compound & $\mathbf{3 a}$ & $3 \mathbf{b}$ \\
\hline Empirical formula & $\mathrm{C}_{19} \mathrm{H}_{22} \mathrm{O}_{3} \mathrm{Si}$ & $\mathrm{C}_{20} \mathrm{H}_{25} \mathrm{NO}_{3} \mathrm{Si}$ \\
\hline Formula weight & 326.46 & 355.50 \\
\hline Temperature & $296(2) \mathrm{K}$ & $296(2) \mathrm{K}$ \\
\hline Wavelength & $0.71073 \AA$ & $0.71073 \AA$ \\
\hline Crystal system, space group & Monoclinic, $P 2_{1} / \mathrm{c}$ & Triclinic, $P \overline{1}$ \\
\hline \multicolumn{3}{|l|}{ Unit cell dimensions } \\
\hline $\mathrm{a}$ & $16.070(7) \AA$ & $9.0565(11)$ \\
\hline $\mathrm{b}$ & $17.935(7) \AA$ & $9.9342(12)$ \\
\hline $\mathrm{c}$ & $13.160(5) \AA$ & $11.7672(15)$ \\
\hline$\alpha\left(^{\circ}\right)$ & 90 & $84.659(4)$ \\
\hline$\beta\left({ }^{\circ}\right)$ & $112.360(7)$ & $69.482(4)$ \\
\hline$\gamma\left({ }^{\circ}\right)$ & 90 & $77.424(4)$ \\
\hline Volume $\AA^{3}$ & $3508(2)$ & $967.6(2)$ \\
\hline $\mathrm{Z}$ & 8 & 2 \\
\hline Calculated density $\left(\mathrm{Mg} / \mathrm{m}^{3}\right)$ & 1.236 & 1.220 \\
\hline Absorption coefficient $\left(\mathrm{mm}^{-1}\right)$ & 0.146 & 0.139 \\
\hline $\mathrm{F}(000)$ & 1392 & 380 \\
\hline Crystal size (mm) & $0.18 \times 0.16 \times 0.16$ & $0.18 \times 0.16 \times 0.16$ \\
\hline Theta range for data collection & 1.78 to $27.00 \mathrm{deg}$. & 1.85 to 27.00 \\
\hline \multirow[t]{3}{*}{ Limiting indices } & $-20<=\mathrm{h}<=20$ & $-11<=\mathrm{h}<=11$ \\
\hline & $-22<=\mathrm{k}<=22$ & $-12<=\mathrm{k}<=12$ \\
\hline & $-16<=1<=16$ & $-15<=1<=15$ \\
\hline \multirow[t]{2}{*}{ Reflections collected/unique } & $38323 / 7653$ & $22289 / 4189$ \\
\hline & {$[\mathrm{R}(\mathrm{int})=0.0561]$} & {$[\mathrm{R}(\mathrm{int})=0.0428]$} \\
\hline Completeness to theta & $27.00100 .0 \%$ & $27.0098 .9 \%$ \\
\hline Max. and min. transmission & 0.9770 and 0.9742 & 0.9781 and 0.9754 \\
\hline Refinement method & Full-matrix least-squares on $\mathrm{F}^{2}$ & Full-matrix least-squares on $\mathrm{F}^{2}$ \\
\hline Data/restraints/parameters & $7653 / 0 / 431$ & $4189 / 0 / 229$ \\
\hline Goodness-of-fit on $\mathrm{F}^{2}$ & 0.968 & 0.962 \\
\hline \multirow[t]{2}{*}{ Final $\mathrm{R}$ indices $[\mathrm{I}>2 \operatorname{sigma}(\mathrm{I})]$} & $\mathrm{R} 1=0.0676$ & $\mathrm{R} 1=0.0451$ \\
\hline & $\mathrm{wR} 2=0.1334$ & $\mathrm{wR} 2=0.1044$ \\
\hline \multirow[t]{2}{*}{$\mathrm{R}$ indices (all data) } & $\mathrm{R} 1=0.1190$ & $\mathrm{R} 1=0.0645$ \\
\hline & $\mathrm{wR} 2=0.1508$ & $\mathrm{wR} 2=0.1122$ \\
\hline Largest diff. peak and hole (e. $\left.\mathrm{A}^{-3}\right)$ & 0.273 and -0.217 & 0.213 and -0.267 \\
\hline
\end{tabular}


protons. All this information attributed to the formation of compounds $\mathbf{3 a}$ and $\mathbf{3 b}$. All other analytical data were in good agreement with the reported chemical structure. ${ }^{17}$

\subsection{Crystallography}

Summary of crystallographic data and other structure refinement parameters of the compound 3a are as shown in table 1. Tables 2 and 3 show the respective hydrogen bond interactions in compounds $\mathbf{3 a}$ and $\mathbf{3 b}$, respectively. The ORTEP diagram of the two independent molecules present in the asymmetric unit of compound 3a, showing 50\% probability ellipsoids and the atom numbering scheme is shown in figure 1 . The ORTEP view of the molecule $\mathbf{3 b}$ with atom labelling (thermal ellipsoids drawn at $50 \%$ probability) is shown in figure 2. Figures 3 and 5 show the $\mathrm{C}-$ $\mathrm{H}$... O intermolecular interaction in compounds $\mathbf{3 a}$ and $\mathbf{3 b}$, respectively. Figure 4 shows the $\pi-\pi$ interaction in compound $\mathbf{3 a}$.

In compound 3a there are two independent molecules in the asymmetric unit. One of the oxygen atom of one molecule is disordered over two sites with an occupancy ratio of 0.754 (2):0.246 (1), resulting in a major and a minor conformer. The bicyclic eight-membered rings are substituted with naphthaquinone at the one side and the silyloxy-group at the other side. Both the substituents are endo- to the bicyclic rings with dihedral angles of $108^{\circ}$ and $115^{\circ}$, respectively. In the molecule, cyclohexene rings $\mathrm{A}(\mathrm{C} 6 \mathrm{~B} / \mathrm{C} 9 \mathrm{~B} / \mathrm{C} 8 \mathrm{~B} / \mathrm{C} 5 \mathrm{~B} / \mathrm{C} 10 \mathrm{~B} / \mathrm{C} 7 \mathrm{~B})$ and $\mathrm{B}(\mathrm{C} 7 \mathrm{~B} / \mathrm{C} 8 \mathrm{~B} / \mathrm{C} 9 \mathrm{~B} / \mathrm{C} 10 \mathrm{~B} / \mathrm{C} 11 \mathrm{~B} / \mathrm{C} 12 \mathrm{~B})$, and the cyclohexane ring $\mathrm{C}(\mathrm{C} 5 \mathrm{~B} / \mathrm{C} 6 \mathrm{~B} / \mathrm{C} 10 \mathrm{~B} / \mathrm{C} 11 \mathrm{~B} / \mathrm{C} 12 \mathrm{~B} / \mathrm{C} 7 \mathrm{~B})$ of the bicyclo[2.2.2] octene unit adopt distorted boat

Table 2. Non-bonded interactions and possible hydrogen bonds $\left(\AA,^{\circ}\right)$ for compound 3a (D-donor; A-acceptor; H-hydrogen).

\begin{tabular}{|c|c|c|c|c|}
\hline $\mathrm{D}-\mathrm{H} \cdots \mathrm{A}$ & D-H & $\mathrm{H} \cdots \mathrm{A}$ & D. $\cdots A$ & $\mathrm{D}-\mathrm{H} \cdots \mathrm{A}$ \\
\hline C17A-H17A...O2B ${ }^{\mathrm{i}}$ & 0.930 & 2.494 & $3.182(5)$ & 130 \\
\hline C18A-H18A...O2A & 0.930 & 2.668 & $3.493(4)$ & 148 \\
\hline
\end{tabular}

Symmetry code: (i) $-\mathrm{x},+\mathrm{y}+1 / 2,-\mathrm{z}+1 / 2$, (ii) $\mathrm{x},-\mathrm{y}+1 / 2+1,+\mathrm{z}-1 / 2$

Table 3. Non-bonded interactions and possible hydrogen bonds $\left(\AA{ }^{\circ},{ }^{\circ}\right)$ for compound $\mathbf{3 b}$ (D-donor; A-acceptor; H-hydrogen).

\begin{tabular}{|c|c|c|c|c|}
\hline $\mathrm{D}-\mathrm{H} \cdots \mathrm{A}$ & D-H & $\mathrm{H} \cdots \mathrm{A}$ & $\mathrm{D} \cdots \mathrm{A}$ & $\mathrm{D}-\mathrm{H} \cdots \mathrm{A}$ \\
\hline $\mathrm{C} 2-\mathrm{H} 2 \ldots \mathrm{O} 1^{\mathrm{i}}$ & 0.980 & 2.485 & $3.359(2)$ & 148 \\
\hline $\mathrm{C} 4-\mathrm{H} 4 \mathrm{~A} \ldots \mathrm{...O} 2^{\mathrm{ii}}$ & 0.970 & 2.490 & $3.343(2)$ & 146 \\
\hline
\end{tabular}

Symmetry code: (i) $-\mathrm{x}+1,-\mathrm{y}+2,-\mathrm{z}+1$, (ii) $-\mathrm{x},-\mathrm{y}+2,-\mathrm{z}+2$

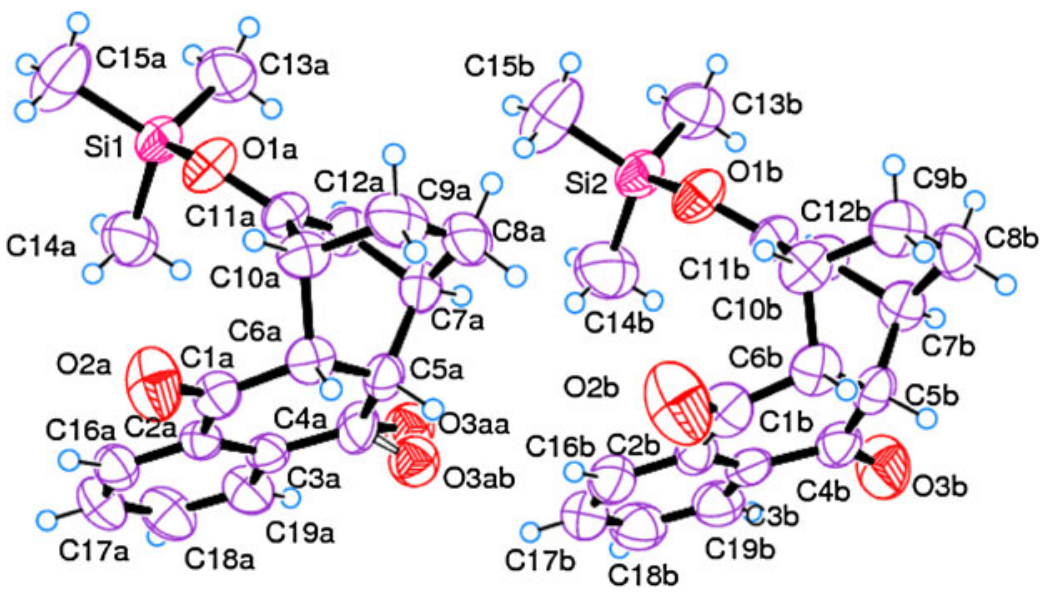

Figure 1. ORTEP diagram of the two independent molecules present in the asymmetric unit of compound $\mathbf{3 a}$, showing $50 \%$ probability ellipsoids and the atom numbering scheme. 


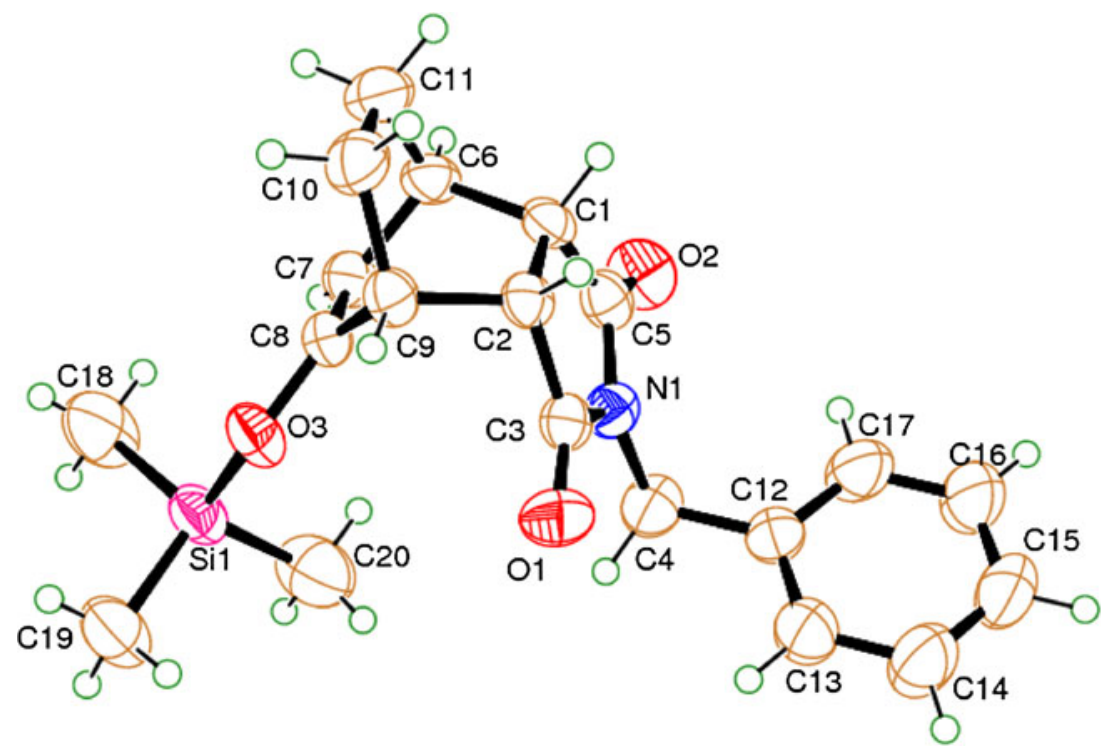

Figure 2. ORTEP view of compound $\mathbf{3 b}$, showing $50 \%$ probability ellipsoids and the atom-numbering scheme.

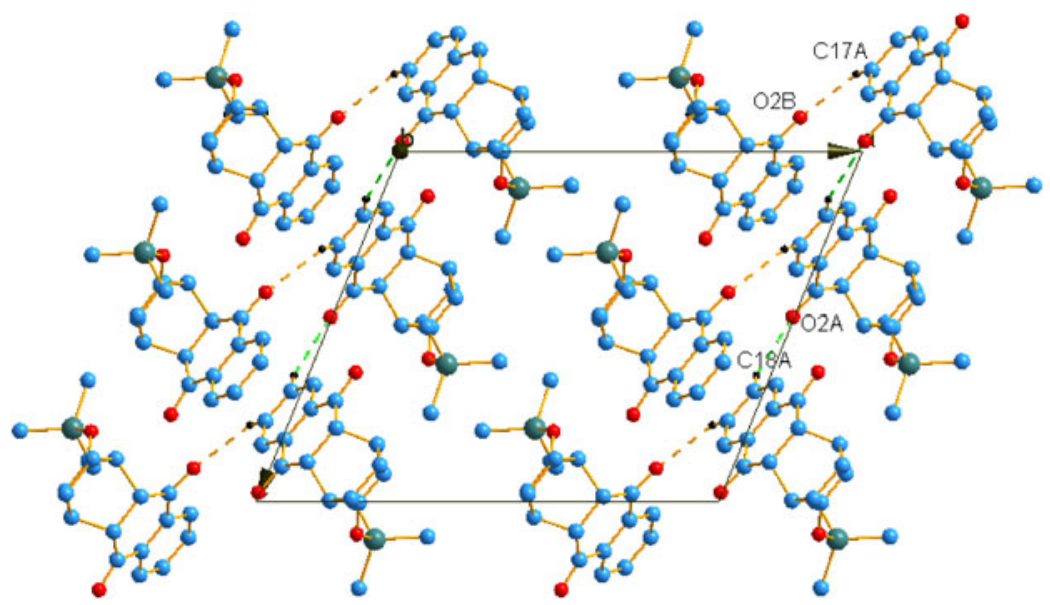

Figure 3. Crystal structure of 3a viewed along 'c' axis. Dotted lines indicate intermolecular C-H... O interactions.

like conformations as reported earlier. ${ }^{18}$ The ring puckering parameters $\mathrm{Q}, \theta$ and $\phi$ are 0.875 (2) $\AA$, $-60.15(2)^{\circ}$ and $90.4(1)^{\circ}$, respectively for ring $\mathrm{A}$, $0.786(2) \AA,-179.85(2)^{\circ}$ and $90.41(2)^{\circ}$, respectively for ring $\mathrm{B}$, and $0.816(2) \AA, 119.93(2)^{\circ}$ and $90.14(2)^{\circ}$, respectively for ring C. ${ }^{19}$

The crystal structure of the compound 3a is stabilized by two types of $\mathrm{C}-\mathrm{H}$... O intermolecular interactions. These interactions result in the formation of chains along 'c' axis (figure 3). The molecular packing is further stabilized by $\pi-\pi$ stacking interactions between naphthaquinone rings with the shortest centroid-centroid distance being 3.636 ̊ for C3A-C2B carbons (figure 4).

Compound 3b crystallizes in triclinic crystal system with space group Pì (figure 5). The bicyclo[2.2.2] octene ring is substituted with $\mathrm{N}$-benzylmaleimide at one end and the trimethylsilyloxy-group at the other end. Due to steric-hindrance in the ring both the substituents adopt endo-conformation, this is in good agreement with the theoretical predictions. ${ }^{20,21}$ The phenyl ring of $N$-benzylmaleimide group is positioned axially to the methyl-pyrrolidine-2,5-dione ring with a dihedral angle of $67.36(5)^{\circ}$. In the molecule, cyclohexene rings $\mathrm{A}(\mathrm{C} 6 / \mathrm{C} 7 / \mathrm{C} 8 / \mathrm{C} 9 / \mathrm{C} 10 / \mathrm{C} 11)$ and $\mathrm{B}(\mathrm{C} 6 / \mathrm{C} 7 / \mathrm{C} 8 / \mathrm{C} 9 /$ $\mathrm{C} 1 / \mathrm{C} 2)$, and the cyclohexane ring $\mathrm{C}(\mathrm{C} 6 / \mathrm{C} 1 / \mathrm{C} 2 / \mathrm{C} 9 /$ $\mathrm{C} 10 / \mathrm{C} 11)$ of the bicyclo[2.2.2] octene unit, all the three rings adopt distorted boat conformations as seen in compound 3a. The ring puckering parameters $\mathbf{Q}, \theta$ and $\phi$ are 0.787 (2) $\AA, 89.29(1)^{\circ}$ and $0.787(2)^{\circ}$, respectively for ring A, 0.81 (2) $\AA, 94.31(2)^{\circ}$ and 176.46 $(2)^{\circ}$, respectively for ring B, and 0.889 (2) $\AA$, $90.7(1)^{\circ}$ 

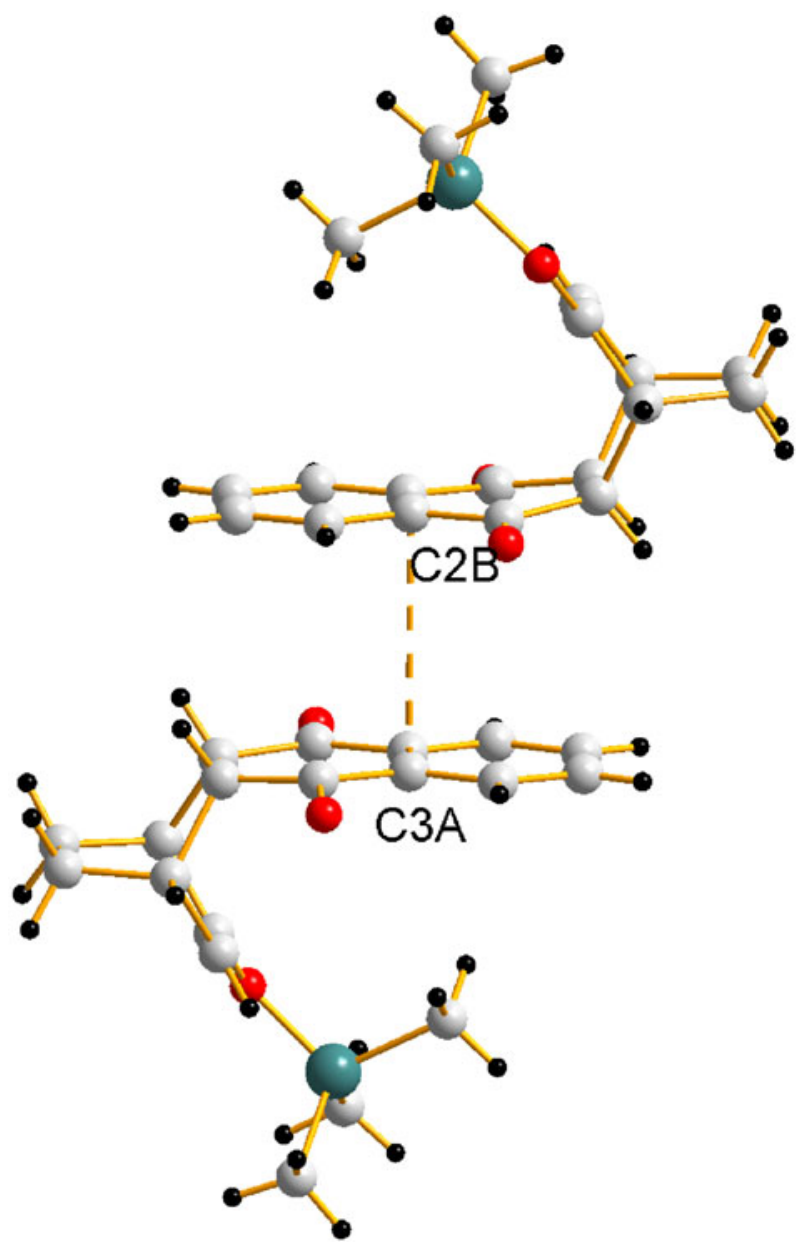

Figure 4. Compound 3a, showing $\pi-\pi$ stacking interactions between naphthaquinone rings.

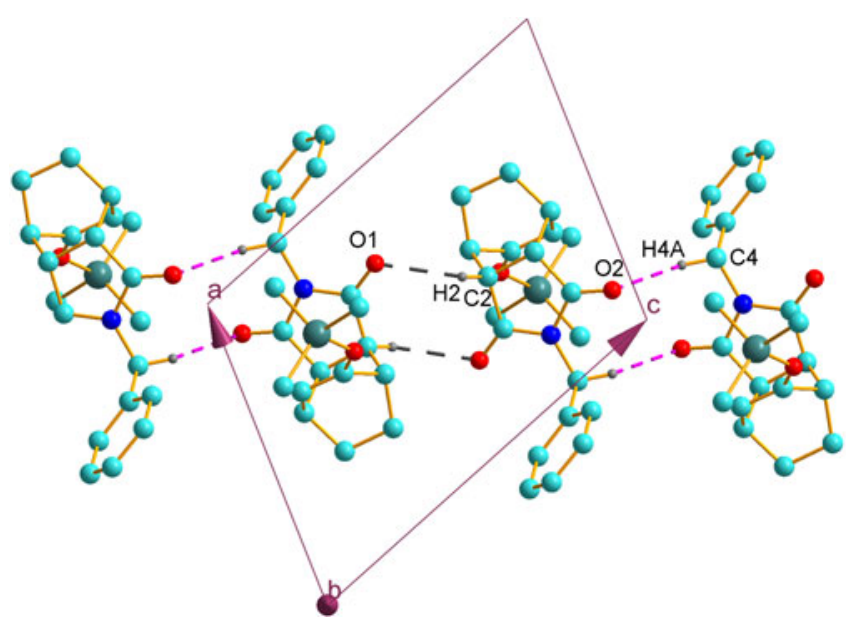

Figure 5. Molecular packing of compound $\mathbf{3 b}$ viewed along 'a-c' diagonal plane. Dotted lines indicate intermolecular $\mathrm{C}-\mathrm{H}$. . . O interactions.

and $-176.25(1)^{\circ}$, respectively for ring C. ${ }^{19}$ Both the oxygen atoms of the pyrrolidine-2,5-dione ring are taking part in the hydrogen bond.
The crystal structure is stabilized by two types of C$\mathrm{H}$. . . O intermolecular interactions, both the interactions result in the formation of centrosymmetric head-to-head dimers generating one-dimensional chain along ' $\mathrm{a}-\mathrm{c}$ ' diagonal plane with graph set motif $\mathrm{R}_{2}^{2}(8)$ and $\mathrm{R}_{2}^{2}(10)$, respectively.

The overall conformation in compounds $\mathbf{3 a}$ and 3b are very similar. For example, the dihedral angle between the three rings of bicyclo[2.2.2] oct-5-ene unit of compound $3 \mathbf{a}$ is $108^{\circ} / 108^{\circ}, 109^{\circ} / 108^{\circ}, 108^{\circ} / 108^{\circ}$, and the compound $\mathbf{3 b}$ is $108^{\circ}, 107^{\circ}$ and $106^{\circ}$. The substituents in both the compounds are endo- to each other.

\section{Conclusion}

We report the synthesis of two trimethylsilyloxysubstituted bicyclo[2.2.2] octene derivatives by DielsAlder $\left[{ }_{4} \pi_{s}+{ }_{2} \pi_{s}\right]$ cycloaddition reactions using ultrasound conditions. Single crystal X-ray diffraction studies showed both the products to have endo- stereochemistry. The molecular structures reveal that there is presence of $\mathrm{C}-\mathrm{H} \ldots \mathrm{O}$ and $\pi-\pi$ interactions that stabilize the structure.

\section{Supplementary material}

The CIF files are deposited at the Cambridge Crystallographic Data Centre, The deposition number of compound $\mathbf{3 a}$ is CCDC-892079 and $\mathbf{3 b}$ is CCDC-892080.

\section{Acknowledgements}

HP and NSB are thankful to the University Grants Commission (UGC) and the Department of Science and Technology (DST), New Delhi, India for the financial assistance.

\section{References}

1. Zhao F, Zhang S and Xi Z 2011 Chem. Commun. 47 4348

2. (a) Paquette L A 1986 Chem. Rev. 86 733; (b) Bois M and Skrydstrup T 1995 Chem. Rev. 951253

3. Williams R V, Todime M M R, Enemark P, van der Helm D and Rizvi S K 1993 J. Org. Chem. 586740

4. Mukherjee S and Corey E J 2010 Org. Lett. 12632

5. Hofmann M A, Nachbauer A, Bergstrager U and Regitz M 1999 Eur. J. Org. Chem. 19991041

6. (a) Hariprasad S 2004 Resonance 80; (b) Langkopf E and Schinzer D 1995 Chem. Rev. 951375

7. (a) Fleming I, Barbero A and Walter D 1997 Chem. Rev. 97 2063; (b) Birney D, Lim T K, Koh J H P, Pool B R and White J M 2002 J. Am. Chem. Soc. 1245091

8. (a) Goh Y W, Danczak S M, Lim T K and White J M 2006 J. Org. Chem. 72 2929; (b) Bats J W, Urschel B and Muller T 2008 Acta Crystalogr. E64 o2235 
9. (a) Begum N S, Girija C R, and Nagendrappa G 2004 Cryst. Eng Commun. 6 116; (b) Begum N S, Girija C R, Mallya N M and Nagendrappa G 2005 J. Mol. Struct. 751 127; (c) Begum N S, Vasundhara D E, Girija C R and Nagendrappa G 2008 Acta Crystalgr. C64 o423

10. Nicolaou K C, Snyder S A, Montagnon $T$ and Vassilikogiannakis G 2002 Angew. Chem. Int. Ed. 41 1668

11. Buckle R N, Liu P Y, Roberts E W D and Burnell D J 1999 Tetrahedron $\mathbf{5 5} 11455$

12. Gerard J 2002 Tetrahedron 585185

13. Bruker 1998 SMART, SAINT-plus and SADBAS (Madison, Wisconsin, USA: Bruker AXS Inc)
14. Sheldrick G M 2008 Acta Crystalogr. A64 112

15. Farrugia L J and ORTEP-3 1999 J. Appl. Crystalogr. 32 837

16. Nardelli M 1983 Acta Cryst. C39 1141

17. Srinivasa H T and HariPrasad S 2012 Org. Commun. 5(3) 128

18. Orhan B, Serkan Y, Mustafa O, Ozgur P and Yilmaz Y 2009 Acta Crystalogr. E65 o2208

19. Cremer D and Pople J A 1975 J. Am. Chem. Soc. 97 1354

20. Reymond S and Cossy J 2008 Chem. Rev. 1085359

21. Pidaparthi R R, Junker C S, Welker M E, Day C S and Wright M W 2009 J. Org. Chem. 748290 